\title{
1-Oxa-3-azapentalen-2-ones as precursors of cis-2-amino alcohols: synthesis from acetylenic alcohols, carbon dioxide and amines via intramolecular amidoalkylation of oxazolidinones
}

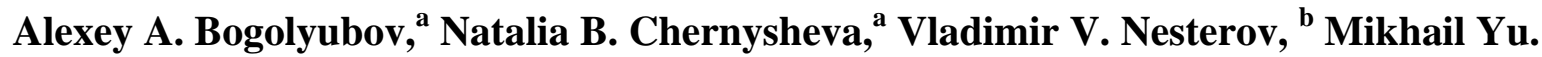 \\ Antipin ${ }^{b}$, and Victor V. Semenov* a \\ ${ }^{a}$ N.D. Zelinsky Institute of Organic Chemistry, Russian Academy of Science, \\ 47 Leninsky prosp., 117913 Moscow, Russian Federation \\ ${ }^{b}$ A.N. Nesmeyanov Institute of Organoelement Compounds, Russian Academy \\ of Science, 28 ul. Vavilova, 117813 Moscow, Russian Federation \\ E-mail:vs@cacr.ioc.ac.ru
}

(received 10 May 00; accepted 21 Sep 00; published on the web 29 Sep 00)

\begin{abstract}
The reaction of 4-methyl-4-(4-methyl-3-pentenyl)-5-methylen-1,3-dioxolan-2-one 1a with primary amines 2 leads to the corresponding 4-hydroxy-4-methyloxazolidin-2-ones 3 which are transformed by intramolecular amidoalkylation into 1-oxa-3-azapentalen-2-ones $\mathbf{4}$ and $\mathbf{5}$, potential precursors of cyclopentane cis-2-amino alcohols.
\end{abstract}

Keywords: Oxazolidinones, amidoalkylation, Lewis bases 


\section{Introduction}

Some chiral 2-amino alcohols are of considerable interest as catalysts for asymmetric DielsAlder reactions, ${ }^{1 \mathrm{a}}$ Michael ${ }^{1 \mathrm{~b}}$ synthesis and enantioselective catalytic reductions. ${ }^{1 \mathrm{c}}$ These alcohols exhibit a wide range of biological activities. We have developed a simple approach to precursors of related cyclopentane cis-2-amino alcohols on the basis of the reaction of dioxolanone 1a with primary amines 2, which results in the formation of intermediate oxazolidinones 3 . Intramolecular amidoalkylation of $\mathbf{3}$ in formic acid gives azapentalenones $\mathbf{4}$ and $\mathbf{5}$ with cisoriented substituents at the annulation centers. Compounds $\mathbf{4}$ and $\mathbf{5}$ are considered to be potential precursors of the alcohols.

Oxazolidinones (3) are often prepared by the addition of organometallic compounds to oxazolidin-2,4-diones. ${ }^{4,5}$ However, this method has disadvantages such as by-product formation, moderate yields and a complicated procedure. There is also a technique to afford 4methoxyoxazolidin-2-ones, compounds related to ours, via $\mathrm{Sn}$ - and Se-organics which provide good yields and stereo-control. ${ }^{6}$ This is a valuable method although it still suffers from some of the problems noted above. The readily available dioxolanones $\mathbf{1}^{3}$ appear to be useful precursors to the oxazolidinones

\section{Results and Discussion}

Preparation of 4-hydroxyoxazolidinones. The highly basicity amines 2 react with dioxolanones 1 to afford yields in the 38-100 \% range during 12-144 h at rt (3a-g, i) and at 110 ${ }^{\circ} \mathrm{C}$ (3h) (Scheme 1). Catalysis by Lewis bases, in our case triethylamine, is a good choice for the less active $\mathrm{N}, \mathrm{N}$-dimethylhydrazine (2f) and amines $\mathbf{2 c}$ and $\mathbf{2 g}$.

The structure of oxazolidinones 3 is supported by ${ }^{1} \mathrm{H}$ NMR: there are signals for both the $\mathrm{OH}-$ group and the methyl group at the NMR spectra. ${ }^{3}$ The methylene protons in $\mathbf{3 a}, \mathbf{3 b}$ and $\mathbf{3 i}$ are two doublets with a small coupling constant due to the asymmetric center at the 4-position of the ring. If there are two asymmetric centers in the oxazolidinone cycle (mixture of two diastereomeric pairs), the NMR spectra interpretation is much more difficult because signal duplication takes place. The mixtures of such diastereomeric pairs display two spots on TLC. These diastereomeric pairs have no sharp melting points (besides some of compounds 3 dehydrate when heated or even at rt). Compound 3a was chromatographically separated to give two pairs 3a' and 3a"; they melt at different temperatures and their ${ }^{1} \mathrm{H}$ NMR spectra are not 
identical. In $\mathrm{CDCl}_{3}$ both pairs are transformed into 3-benzyl-5-methyl-5-(4-methyl-3-pentenyl)4-methylenoxazolidin-2-on by traces of $\mathrm{DCl}$ in a week (characterized with ${ }^{1} \mathrm{H}$ NMR) (Figure 1).


1a: $\mathrm{R}=\mathrm{Dhl}$
1b: $\mathrm{R}=\mathrm{Me}$

2a: $\mathrm{R}_{1}=\mathrm{Bn}$

2b: $\mathrm{R}_{1}=2-\mathrm{PyCH}_{2}$

2c: $\mathrm{R}_{1}=\mathrm{CNCH}_{2} \mathrm{CH}_{2}$

2d: $\mathrm{R}_{1}=\mathrm{CH}_{2}=\mathrm{CHCH}_{2}$

2e: $\mathrm{R}_{1}=\mathrm{HOCH}_{2} \mathrm{CH}_{2}$

2f: $\mathrm{R}_{1}=\mathrm{Me}_{2} \mathrm{~N}$

2g: $\mathrm{R}_{1}=\mathrm{Tzl}$

2h: $\mathrm{R}_{1}=3-\mathrm{PyCH}_{2}$

$\mathrm{Dhl}=\mathrm{Me}_{2}=\mathrm{CHCH}_{2} \mathrm{CH}_{2}$

$\mathrm{Tzl}=-\mathrm{N}$

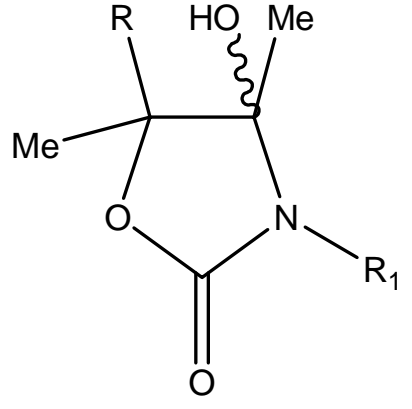

3a: $\mathrm{R}=\mathrm{Dhl}$,

$\mathrm{R}_{1}=\mathrm{Bn}$

3b: $\mathrm{R}=\mathrm{Dhl}$,

$$
\mathrm{R}_{1}=2-\mathrm{PyCH}_{2}
$$

3c: $\mathrm{R}=\mathrm{Dhl}$,

$$
\mathrm{R}_{1}=\mathrm{CNCH}_{2} \mathrm{CH}_{2}
$$

3d: $\mathrm{R}=\mathrm{Me}$,

$$
\mathrm{R}_{1}=\mathrm{CH}_{2}=\mathrm{CHCH}_{2}
$$

3e: $\mathrm{R}=\mathrm{Dhl}$,

$$
\mathrm{R}_{1}=\mathrm{CH}_{2}=\mathrm{CHCH}_{2}
$$

[3f]: $\mathrm{R}=\mathrm{Dhl}$,

$$
\mathrm{R}_{1}=\mathrm{HOCH}_{2} \mathrm{CH}_{2}
$$

3g: $\mathrm{R}=\mathrm{Dhl}$, $\mathrm{R}_{1}=\mathrm{Me}_{2} \mathrm{~N}$

3h: $\mathrm{R}=\mathrm{Dhl}$, $\mathrm{R}_{1}=\mathrm{Tzl}$

3i: $\mathrm{R}=\mathrm{Dhl}$, $\mathrm{R}_{1}=3-\mathrm{PyCH}_{2}$

\section{Scheme 1}




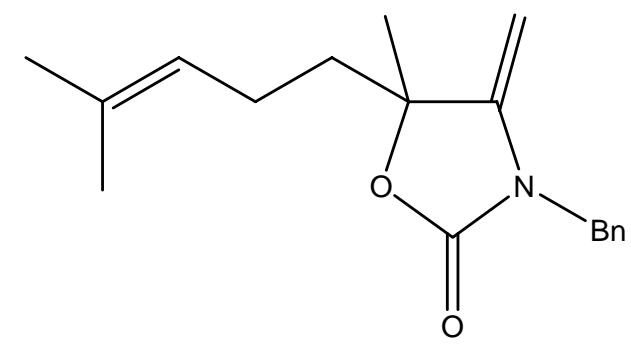

Figure 1. 3-Benzyl-5-methyl-5-(4-methyl-3-pentenyl)-4-methylenoxazolidin-2-one.

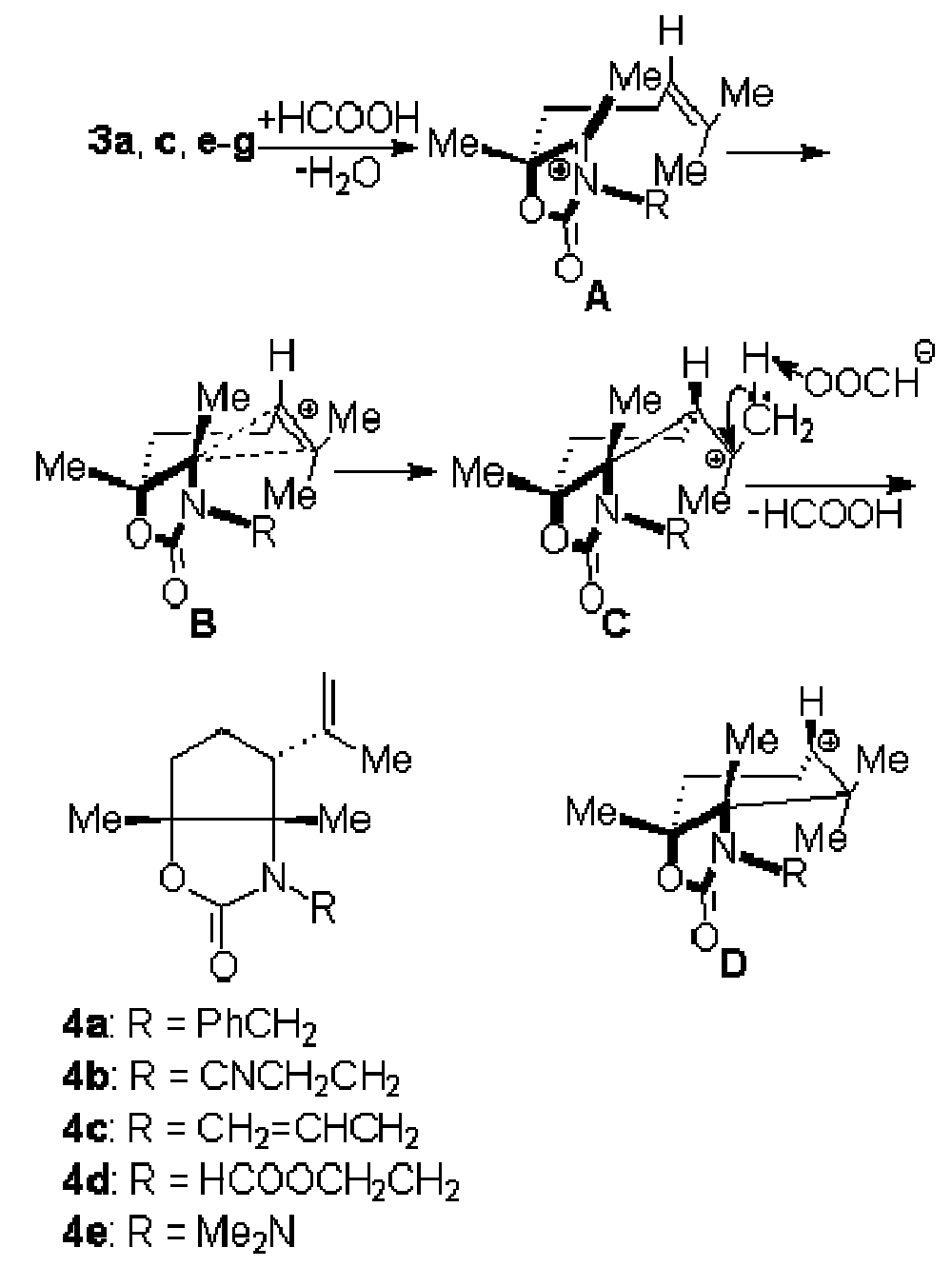

Scheme 2 
Preparation of 1-oxa-3-azapentalen-2-ones. A review ${ }^{7}$ reports on intramolecular amidoalkylation of 4-hydroxytiazolidin-2-one derivatives related to compounds 3 . But only a few papers deal with intramolecular amidoalkylation of oxalidinones $\mathbf{3}$ themselves. ${ }^{4,5}$ Amidoalkylations of oxazolidinones 3 result in azapentalenones 4a-e with yields in $26-96 \%$ over 48-168 $\mathrm{h}$ at ambient temperature (Scheme 2). Allyl groups in compounds 3e and 3d do not participate in amidoalkylation as it would require a geometrically disadvantageous 5-endo-trig transition state. In the case of $\mathbf{4 d}$, acylation of the $\beta$-hydroxyethyl group proceeds in addition to intramolecular amidoalkylation.

We did not attempt to identify the absolute configuration of compounds 4a-e. From the theoretical $^{5,8}$ and $\mathrm{x}$-ray analysis data on compound $\mathbf{5}^{\prime}$ (see below), we suggest that these compounds should have the stereochemical structure presented in Scheme 2. The reaction proceeds through a standard mechanism, i.e. the acyliminium ion reacts with the double bond in A in such a manner that maximum overlapping of molecular orbitals in transition state $\mathbf{B}$ would be achieved, and strain energy in the newly generated cycle would be minimized. The formation of transition state $\mathbf{B}$ is followed by the tertiary carbocation $\mathbf{C}$ generation and five-membered cycle closure. Although this cycle is less beneficial from an energy standpoint than the sixmembered one, the reaction passes in this very direction as the six-membered cycle involves the generation of less stable secondary carbocation $\mathbf{D}$. The stabilization of tertiary ion $\mathrm{C}$ may be achieved in two ways: both by proton loss and anion addition $\left(\mathrm{HCOO}^{-}\right)$. The predominating generation of unsaturated compounds 4a-e makes it possible to assume that the rate of proton elimination is much higher than that of formate-anion addition.

Both processes take place when a nitrogen heterocyclic substituent capable of protonation is available at position 3 of the ring (Scheme 3). In the instance of amidoalkylation of $3 \mathbf{b}$, we


compounds 5' and 5' by chromatography but failed with compounds 4' and 4'. The ${ }^{1} \mathrm{H}$ NMR spectroscopy data on hetero-substituted $\mathbf{3 h}$ and $\mathbf{3 i}$ supports the formation of similar products. A protonated heterocyclic compound capable of coordinating the formate-ion responsible for the generation of formyl derivatives $\mathbf{5}$ is likely to be available. Carbocations $\mathbf{E}$ and $\mathbf{F}$ (analogs of $\mathbf{C}$, Scheme 2) can be stabilized either by proton loss or by the addition of this heterocyclecoordinated formyl anion. The rates of both processes are evidently proportional, and therefore


$\mathbf{4 f} / \mathbf{5}$ is regulated by two counteracting factors in $\mathbf{E}$ and $\mathbf{F}$, i.e. by overlapping of orbitals and


$\mathbf{4 f}^{\prime \prime} / \mathbf{5}$ " are almost equal the counteracting factors are likely to be comparable. 

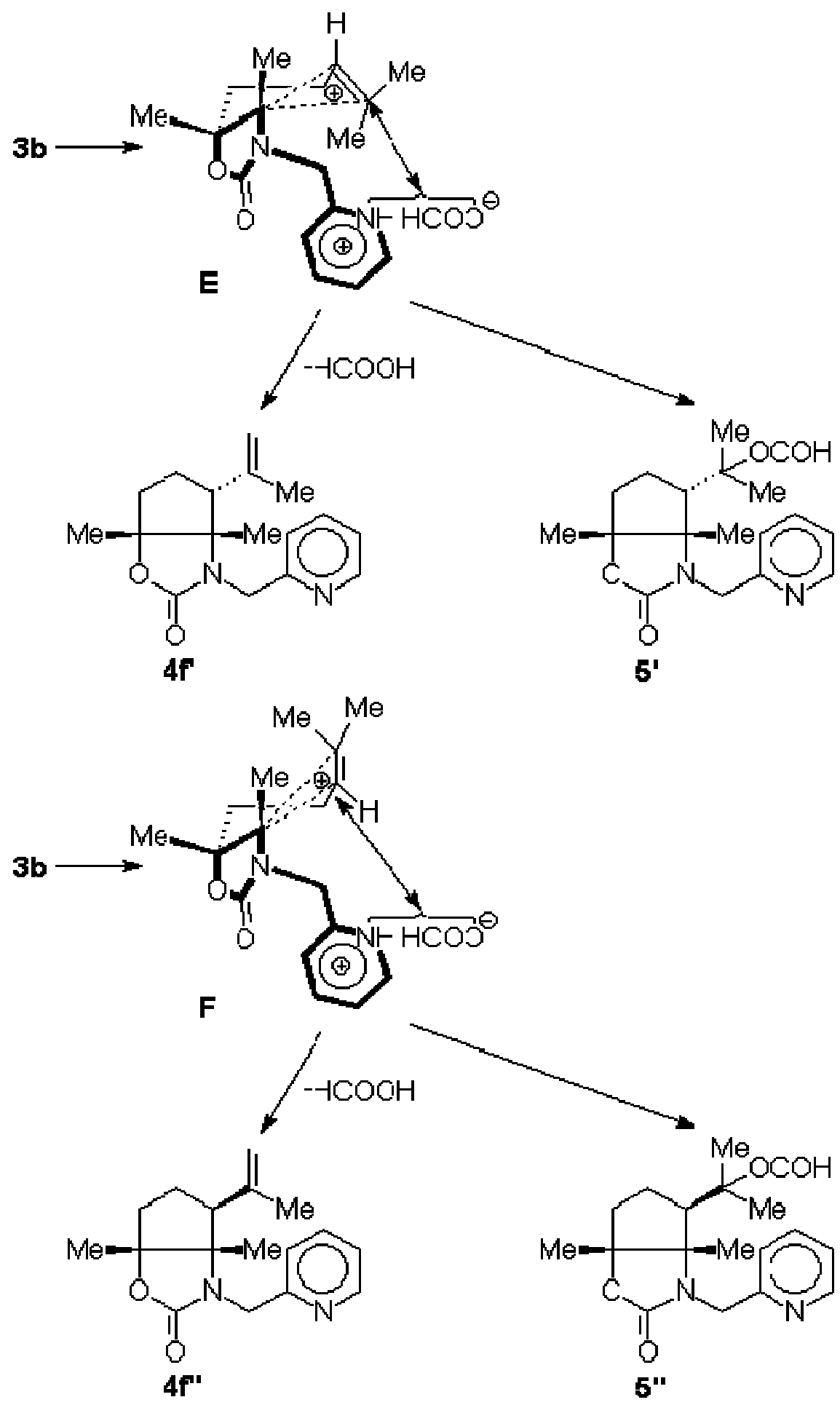

Scheme 3 
The configuration of ester $\mathbf{5}^{\prime}$ in the solid state was proven by x-ray analysis (Figure 2). As expected, the methyl groups at the vicinal atoms of the bicyclic fragment are cis-oriented. The $\mathrm{HCOO}-\mathrm{C}(\mathrm{CH} 3) 2$ group is trans-oriented towards these methyl groups. The torsion angles $\mathrm{C}(22)-$ $\mathrm{C}(12)-\mathrm{C}(11)-\mathrm{C}(21)$ and $\mathrm{C}(13)-\mathrm{C}(14)-\mathrm{C}(15)-\mathrm{C}(16)$ are 25.8(4) and -165.6(3), correspondingly. The oxazolidinone cycle is characterized by the twist conformation with the deviation of $\mathrm{C}(11)$ and $\mathrm{C}(12)$ atoms by 0.218 and -0.186 , correspondingly. The cyclopentane cycle has a distorted envelope conformation with the deviation of $\mathrm{C}(13)$ atom by 0.559 . The angle between these two annulated cycles is 76. Due to formation of weak C-H...O interactions $\mathrm{C}(18)-\mathrm{H}(18) \ldots \mathrm{O}(20)(-\mathrm{x}$,

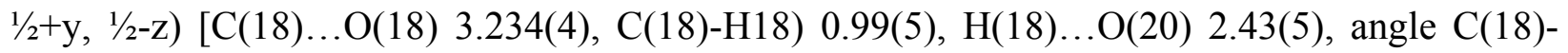
$\mathrm{H}(18) \ldots \mathrm{O}(20) 138(3)]$ the molecules are assembled into helixes directed along $b$ crystallographic axis. Almost all other bond lengths and angles in the molecule have the expected values. ${ }^{9}$

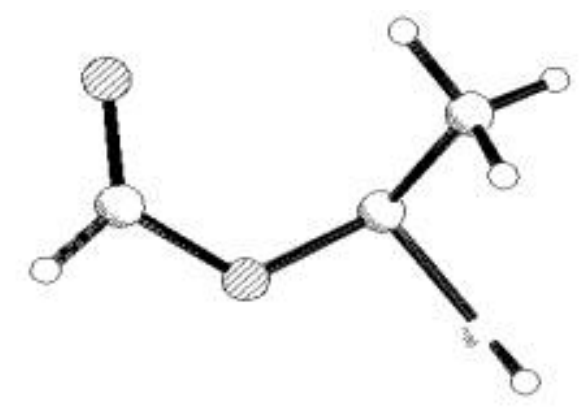

Figure 2. 3a,6a-dimethyl-4-trans-(methyl-1-formyloxy)-4-[(pyridyl-2)methyl]hexahydro-1-oxa3-azapentalen-2-on. 
Stereoisomers 5' and 5" can be feasibly be identified by ${ }^{1} \mathrm{H}$ NMR spectroscopy: signals of the formyl protons and N-CH2-Py protons feature notable distinctions in chemical shifts. Moreover, 5' and 5' are in different aggregate states.

According to the literature data, dilution of the reaction mixture leads to an increase in the yields of azapentalenones. The yield of 4a increases from 54 to $65 \%$ with a decrease of the initial concentration of starting 3a from 0.111 to $0.055 \mathrm{mmol} / \mathrm{mL}$. The mass spectrometry data evidence that the available by-products (viscous oils) have doubled molecular mass versus 3a, minus mass of two water molecules. The products are probably dimeric, whose formation have been discussed in the literature. ${ }^{7}$

\section{Conclusions}

The preparation of compounds $\mathbf{4}$ and $\mathbf{5}$ with the specified stereochemistry has been accomplished. All steps of the synthesis (dioxolanone $\mathbf{1}$ to oxazolidinone $\mathbf{3}$ to azapentalenone $\mathbf{5}$ or/and 4) proceed with good yields and under mild conditions, with easy separation of products $i$ (intermediates $\mathbf{3}$ may be used without isolation).

\section{Experimental Section}

General Procedures. Dioxolanones 1a (4-methyl-4-(4-methyl-3-pentenyl)-5-methylen-1,3dioxolan-2-one) and $\mathbf{1 b}$ (4,4-dimethyl-5-methylen-1,3-dioxolan-2-one) were prepared in accordance with the literature technique. ${ }^{2}$ The ${ }^{1} \mathrm{H}$ NMR spectra were recorded on Bruker WM250, frequency $250 \mathrm{MHz}$. The IR spectra were obtained on a Perkin Elmer 577 (KBr). Mass spectra were obtained on MS-30 [Kratos]. Flash-chromatography on a dry column was used ${ }^{10}$ (column's diameter $6 \mathrm{sm}$, adsorbent Silufol 5/40 in proportion $25 \mathrm{~g}$ per $1 \mathrm{~g}$ of a mixture, eluent benzene-ethyl acetate with increasing polarity, TLC control). An acetone-dry ice cooling bath was used. 
Uncolored crystals of the compound $5^{\prime}\left(\mathrm{C}_{18} \mathrm{H}_{24} \mathrm{~N}_{2} \mathrm{O}_{4}\right)$ were obtained from acetonitrile by a slow three-day crystallization. The crystals are orthorhombic; at $25 \mathrm{C}: a=9.310(5), b=10.907(6), c=$ 17.344(8), $V=1761(2) 3, d$ cacd $=1.254 \mathrm{~g} / \mathrm{sm} 3, Z=4, \mathrm{P} 212121$. The 4242 independent reflections were measured at difractometer Siemens $\mathrm{P} 3 / \mathrm{PC}((\mathrm{MoK})=0.71072$, graphite monochromator, $\Theta / 2 \Theta$-scans, max 28). The structure was solved by a direct method and refined using full-matrix least-squares approximation against F2. All hydrogen atoms were revealed by the difference Fourier electron density synthesis and refined isotropically. The refinement converged to $w R 2=0.162$ for 4188 reflections $(\mathrm{R} 1=0.066$ for 2475 reflections with $I>2(I))$. All calculations were performed at IBM PC/AT-586 with the programs SHELXTL PLUS and SHELXL-93.

\section{3-Benzyl-4,5-dimethyl-3-hydroxy-5-(4-methyl-3-pentenyl)oxazolidin-2-one (3a).}

Dioxolanone 1a $(5.88 \mathrm{~g}, 30 \mathrm{mmol})$ was added with stirring to a suspension of benzylamine hydrochloride (4a) $(4.60 \mathrm{~g}, 32 \mathrm{mmol})$ and sodium hydroxide $(1.28 \mathrm{~g}, 32 \mathrm{mmol})$ in $10 \mathrm{~mL}$ of water. After $24 \mathrm{~h}$ at rt, the mixture was extracted with $25 \mathrm{~mL}$ and then $15 \mathrm{~mL}$ of chloroform. The combined extracts were washed with water, filtered through cotton wool and the solvent was evaporated. The resultant dark oil was triturated with $4 \mathrm{~mL}$ of hexane to affords crystals which were washed with hexane $3 \mathrm{~mL}$; white crystals were obtained $(7.35 \mathrm{~g}, 81 \%), \mathrm{mp} 3 \mathbf{a}=70-72{ }^{\circ} \mathrm{C}$; $0.51 \mathrm{~g}$ of the crystals were separated chromatographically to give $0.13 \mathrm{~g}$ of $3 \mathrm{a}^{\prime}$ and $0.30 \mathrm{~g}$ of 3a'; mp 3a' $=102-107{ }^{\circ} \mathrm{C}$, mp 3a" $=84-87{ }^{\circ} \mathrm{C}$; mass spectra of 3a" is equivalent to one of 3a', MS M+ 303, 204, 203, 153, 128; IR of 3a' and of 3a' '1730, $3350 \mathrm{~cm}^{-1} ; 3 \mathbf{a}^{1}{ }^{1} \mathrm{H} \mathrm{NMR}\left(\mathrm{CDCl}_{3}\right) \delta$ $1.22(3 \mathrm{H}, \mathrm{s}), 1.40-1.73(2 \mathrm{H}, \mathrm{m}), 1.45(3 \mathrm{H}, \mathrm{s}), 1.60(3 \mathrm{H}, \mathrm{s}), 1.66(3 \mathrm{H}, \mathrm{s}), 2.30-2.50(2 \mathrm{H}, \mathrm{m}), 3.87$ $(1 \mathrm{H}, \mathrm{s}), 4.32(1 \mathrm{H}, \mathrm{d}, J=15.0 \mathrm{~Hz}), 4.65(1 \mathrm{H}, \mathrm{d}, J=15.0 \mathrm{~Hz}), 5.06(1 \mathrm{H}, \mathrm{t}), 7.22-7.49(5 \mathrm{H}, \mathrm{m}) ; 3 \mathrm{a} "$ ${ }^{1} \mathrm{H}$ NMR $\left(\mathrm{CDCl}_{3}\right) \delta 1.24(3 \mathrm{H}, \mathrm{s}), 1.33(3 \mathrm{H}, \mathrm{s}), 1.58-1.99(2 \mathrm{H}, \mathrm{m}), 1.59(3 \mathrm{H}, \mathrm{s}), 1.66(3 \mathrm{H}, \mathrm{s})$, 2.07-2.23 (2H, m), $3.60(1 \mathrm{H}, \mathrm{s}), 4.33(1 \mathrm{H}, \mathrm{d}, J=17.8 \mathrm{~Hz}), 4.66(1 \mathrm{H}, \mathrm{d}, J=17.8 \mathrm{~Hz}), 5.12(1 \mathrm{H}$, t), 7.25-7.48 $(5 \mathrm{H}, \mathrm{m})$; dehydration product from 3a' and 3a': ${ }^{1} \mathrm{H}$ NMR $\left(\mathrm{CDCl}_{3}\right) \delta 1.51(3 \mathrm{H}, \mathrm{s})$, $1.54(3 \mathrm{H}, \mathrm{s}), 1.70-2.16(4 \mathrm{H}, \mathrm{m}), 3.95(1 \mathrm{H}, \mathrm{d}, J=3.7 \mathrm{~Hz}), 4.09(1 \mathrm{H}, \mathrm{d}, J=3.7 \mathrm{~Hz}), 4.60(1 \mathrm{H}, \mathrm{d}, J$ $=15.5 \mathrm{~Hz}), 4.72(1 \mathrm{H}, \mathrm{d}, J=15.5 \mathrm{~Hz}), 5.06(1 \mathrm{H}, \mathrm{t}), 7.24-7.40(5 \mathrm{H}, \mathrm{m})$.

\section{4,5-Dimethyl-4-hydroxy-5-(4-methyl-3-pentenyl)-3-[(pyridyl-2)methyl]oxazolidin-2-on (3b).} A solution of 2-aminomethylpyridine (2b) $(2.71 \mathrm{~g}, 25.1 \mathrm{mmol})$ in $5 \mathrm{~mL}$ of dichloromethane was mixed with a solution of dioxolanone 1a $(4.90 \mathrm{~g}, 25 \mathrm{mmol})$ in $15 \mathrm{~mL}$ of dichloromethane and kept $24 \mathrm{~h}$ at $\mathrm{rt}$. The reaction mixture was diluted with $10 \mathrm{~mL}$ of dichloromethane, washed with water, filtered through cotton wool and the solvent was evaporated. The light brown oil was carefully dried in vacuum to yield a viscous oil (7.50 g, 99\%); MS M+ 304, 205, 204, 173, 162; 
IR 1750, $3360 \mathrm{~cm}^{-1} ;{ }^{1} \mathrm{H}$ NMR (DMSO-d $) \delta 1.18(3 \mathrm{H}, \mathrm{s}), 1.29(3 \mathrm{H}, \mathrm{s}), 1.43-1.85(2 \mathrm{H}, \mathrm{m}), 1.60$ $(3 \mathrm{H}, \mathrm{s}), 1.68(3 \mathrm{H}, \mathrm{s}), 1.97-2.20(2 \mathrm{H}, \mathrm{s}), 4.35(1 \mathrm{H}, \mathrm{d}, J=17.6 \mathrm{~Hz}), 4.51(1 \mathrm{H}, \mathrm{d}, J=17.6 \mathrm{~Hz}), 5.12$ $(1 \mathrm{H}, \mathrm{t}), 6.34(1 \mathrm{H}, \mathrm{s}), 7.23-7.40(2 \mathrm{H}, \mathrm{m}), 7.79(1 \mathrm{H}, \mathrm{t}), 8.51(1 \mathrm{H}, \mathrm{d}, J=5.3 \mathrm{~Hz})$.

\section{4,5-Dimethyl-4-hydroxy-5-(4-methyl-3-pentenyl)-3-(2-cyanethyl)oxazolidin-2-on (3c).}

The 3-aminopropionitrile (2c) (2.10 g, $30 \mathrm{mmol})$ and 3-4 drops of triethylamine were added to a solution of dioxolanone 1a $(5.88 \mathrm{~g}, 30 \mathrm{mmol})$ in $20 \mathrm{~mL}$ of dichloromethane and kept $144 \mathrm{~h}$ at $\mathrm{rt}$. The solvent was evaporated, $4 \mathrm{~mL}$ of hexane was added with trituration, a precipitate formed which $\mathrm{w}$ as washed with hexane $(2 \times 5 \mathrm{~mL})$ and crystallized from ether-hexane 4:1, white crystals were obtained $(7.54 \mathrm{~g}, 95 \%) ; \mathrm{mp}=93-102{ }^{\circ} \mathrm{C}$; MS M+ 266, 167, 166, 125, 108.; IR 1740, $3350 \mathrm{~cm}^{-1} ;{ }^{1} \mathrm{H}$ NMR (DMSO-d 6$) \delta 1.25,1.30(3 \mathrm{H}, 2 \mathrm{~s}), 1.34,1.36(3 \mathrm{H}, 2 \mathrm{~s}), 1.46-1.76(2 \mathrm{H}$, $\mathrm{m}), 1.57,1.58(3 \mathrm{H}, 2 \mathrm{~s}), 1.62,1.63(3 \mathrm{H}, 2 \mathrm{~s}), 1.96-2.17(2 \mathrm{H}, \mathrm{m}), 2.60-2.75(2 \mathrm{H}, \mathrm{m}), 3.35(2 \mathrm{H}, \mathrm{t})$, 5.03-5.17 (1H, m), $6.11(1 \mathrm{H}, \mathrm{s})$.

\section{3-Allyl-4-hydroxy-4,4,5-trimethyloxazolidin-2-one (3d).}

Allylamine (2d) (2.28 g, $40 \mathrm{mmol}$ ) was added to a solution of dioxolanone $\mathbf{1 b}$ (5.12 g, $40 \mathrm{mmol})$ in $20 \mathrm{~mL}$ of dichloromethane upon cooling to $\mathrm{rt}$. After $12 \mathrm{~h}$ the solvent was evaporated, a partially crystalline colorless oil was washed with hexane-benzene 10:1 ( 3 x $3 \mathrm{~mL}$ ), white crystals were obtained $(7.40 \mathrm{~g}, 100 \%) ; \mathrm{mp}=50-52{ }^{\circ} \mathrm{C}$; MS M+ 185, 168, 167, 127, 123; IR 1740, $3320 \mathrm{~cm}^{-1} ;{ }^{1} \mathrm{H}$ NMR $\left(\mathrm{CDCl}_{3}\right) \delta 1.36(3 \mathrm{H}, \mathrm{s}), 1.37(3 \mathrm{H}, \mathrm{s}), 1.47(3 \mathrm{H}, \mathrm{s}), 3.78-4.03(2 \mathrm{H}, \mathrm{m})$, $3.91(1 \mathrm{H}, \mathrm{s}), 5.15(1 \mathrm{H}, \mathrm{d}$ of d, $J=1.0, J=9.6 \mathrm{~Hz}), 5.25(1 \mathrm{H}, \mathrm{d}$ of d, $J=1.0, J=18.4 \mathrm{~Hz}), 5.80$ $6.00(1 \mathrm{H}, \mathrm{m})$.

\section{3-Allyl-4-hydroxy-4,5-dimethyl-5-(4-methyl-3-pentenyl)oxazolidin-2-one (3e).}

Allylamine (2d) (1.71 g, $30 \mathrm{mmol})$ was added to a solution of dioxolanone $1 \mathrm{a}$ (5.88 g, $30 \mathrm{mmol})$ in $20 \mathrm{~mL}$ of dichloromethane. After $96 \mathrm{~h}$ at rt, the solvent was evaporated, $10 \mathrm{~mL}$ of hexane was added with trituration, the precipitated crystals were washed with hexane $(3 \times 3 \mathrm{~mL})$ to afford a snow-white product $(4.80 \mathrm{~g}, 63 \%)$. The substance did not have a sharp $\mathrm{mp}$ and melted in the interval 40-70 ${ }^{\circ} \mathrm{C}$; MS M+ 253, 154, 111, 108, 85; IR 1725, $3330 \mathrm{~cm}^{-1} ;{ }^{1} \mathrm{H} \mathrm{NMR}\left(\mathrm{CDCl}_{3}\right) \delta 1.36$ $(3 \mathrm{H}, \mathrm{s}), 1.42(3 \mathrm{H}, \mathrm{s}), 1.50-1.78(2 \mathrm{H}, \mathrm{m}), 1.60(3 \mathrm{H}, \mathrm{s}), 1.69(3 \mathrm{H}, \mathrm{s}), 2.03-2.28(2 \mathrm{H}, \mathrm{m}), 3.78-4.00$ $(2 \mathrm{H}, \mathrm{m}), 3.87(1 \mathrm{H}, \mathrm{s}), 5.08(1 \mathrm{H}, \mathrm{t}), 5.15(1 \mathrm{H}, \mathrm{d}$ of d, $J=1.0, J=8.8 \mathrm{~Hz}), 5.22(1 \mathrm{H}, \mathrm{d}$ of d, $J=$ $1.0, J=17.7 \mathrm{~Hz}), 5.62-5.92(1 \mathrm{H}, \mathrm{m})$. 
4,5-Dimethyl-4-hydroxy-3-dimethylamino-5-(4-methyl-3-pentenyl)oxazolidin-2-one (3g). Dioxolanone 1a $(5.40 \mathrm{~g}, 27.55 \mathrm{mmol})$ was added to N,N-dimethylhydrazine (2f) $(2.07 \mathrm{~g}, 34.44$ mmol) upon cooling to $\mathrm{rt}$ and then $2 \mathrm{~mL}$ of triethylamine was added. After $96 \mathrm{~h}$ at $\mathrm{rt}$, the crystals were dissolved in $10 \mathrm{~mL}$ of benzene. The solvent with traces of $\mathbf{2 f}$ and triethylamine was evaporated at $50-60{ }^{\circ} \mathrm{C}$ under reduced pressure. The paste-like precipitate was mixed with $5 \mathrm{~mL}$ of ether with vigorous stirring at $5-10{ }^{\circ} \mathrm{C}$. The product was washed with cool ether $(3 \mathrm{x} 5 \mathrm{~mL})$ to afford $3.52 \mathrm{~g}$ of $\mathbf{3 g}$ as white crystals. The combined washings were allowed to evaporate in air, which yielded an additional $0.52 \mathrm{~g}$ of $\mathbf{3 g}$; total yield was $4.04 \mathrm{~g}(57 \%)$ of white crystals; $\mathrm{mp}=$ 84-87 ${ }^{\circ} \mathrm{C}$; MS M+ 256, 151, 104, 87, 86; IR 1710, $3320 \mathrm{~cm}^{-1 ; 1} \mathrm{H}$ NMR $\left(\mathrm{CDCl}_{3}\right) \delta 1.32(3 \mathrm{H}, \mathrm{s})$, $1.46(3 \mathrm{H}, \mathrm{s}), 1.61(3 \mathrm{H}, \mathrm{s}), 1.69(3 \mathrm{H}, \mathrm{s}), 1.70-1.90(2 \mathrm{H}, \mathrm{m}), 2.05-2.18(2 \mathrm{H}, \mathrm{m}), 2.85(6 \mathrm{H}, \mathrm{s}), 5.11$ $(1 \mathrm{H}, \mathrm{t})$.

4,5-Dimethyl-4-hydroxy-5-(4-methyl-3-pentenyl)-3-(1,2,4-triazolyl-4)oxazolidine-2-one (3h). A mixture of 4-amino-1,2,4-triazol (2g) (1.68 g, $20 \mathrm{mmol})$, dioxolanone 1a (3.96 g, $20.2 \mathrm{mmol})$, $0.5 \mathrm{~mL}$ of triethylamine and $0.5 \mathrm{~mL}$ of DMFA was heated with reflux for $24 \mathrm{~h}$ at $110^{\circ} \mathrm{C}$, and then cooled to rt. The reaction mixture was treated with $10 \mathrm{~mL}$ of ether with trituration; crystals formed which were washed with ether $(4 \times 5 \mathrm{~mL})$. A white powder was obtained $(2.15 \mathrm{~g}, 38 \%)$; $\mathrm{mp}=122-129{ }^{\circ} \mathrm{C}$; MS M+ 280, 151, 129, 111, 110; IR 1770, $3320 \mathrm{~cm}^{-1} ;{ }^{1} \mathrm{H}$ NMR (DMSO-d 6 ) $\delta$ 1.27, $1.28(3 \mathrm{H}, 2 \mathrm{~s}), 1.48,1.53(3 \mathrm{H}, 2 \mathrm{~s}), 1.67(3 \mathrm{H}, \mathrm{s}), 1.69(3 \mathrm{H}, \mathrm{s}), 1.70-1.98(2 \mathrm{H}, \mathrm{m}), 2.00-2.25$ $(2 \mathrm{H}, \mathrm{m}), 5.16(1 \mathrm{H}, \mathrm{t}), 7.00(1 \mathrm{H}, \mathrm{s}), 8.68(2 \mathrm{H}, \mathrm{s})$.

\section{4,5-Dimethyl-4-hydroxy-5-(4-methyl-3-pentenyl)-3-[(pyridyl-3)methyl]oxazolidin-2-one} (3i).

A solution of 3-aminomethylpyridine (2h) $(2.71 \mathrm{~g}, 25.1 \mathrm{mmol})$ in $5 \mathrm{~mL}$ of dichloromethane was mixed with a solution of dioxolanone $1 \mathrm{a}(4.90 \mathrm{~g}, 25 \mathrm{mmol})$ in $15 \mathrm{~mL}$ of dichloromethane. After $72 \mathrm{~h}$ at $\mathrm{rt}$ the reaction mixture was diluted with $10 \mathrm{~mL}$ of dichloromethane. The solution was washed with water and filtered through cotton wool. After solvent evaporation, a substance formed which was crystallized from $9.5 \mathrm{~mL}$ of benzene-hexane 4:1 to yield a light yellow powder (6.76 g, 89\%); mp = 93-102 ${ }^{\circ} \mathrm{C}$; MS M+ 276, 204, 111, 94, 93; IR 1770, $3320 \mathrm{~cm}^{-1}$; ${ }^{1} \mathrm{H}$ NMR (DMSO-d $)_{6} \delta 1.21,1.23(3 \mathrm{H}, 2 \mathrm{~s}), 1.30(3 \mathrm{H}, \mathrm{s}), 1.42-1.63(2 \mathrm{H}, \mathrm{m}), 1.44,1.50(3 \mathrm{H}, 2 \mathrm{~s})$, 1.60, $1.62(3 \mathrm{H}, 2 \mathrm{~s}), 1.92-2.17(2 \mathrm{H}, \mathrm{m}), 4.30(1 \mathrm{H}, \mathrm{d}, J=17.3 \mathrm{~Hz}), 4.63(1 \mathrm{H}, \mathrm{d}, J=17.3 \mathrm{~Hz}), 5.10$ $(1 \mathrm{H}, \mathrm{t}), 6.10(1 \mathrm{H}, \mathrm{s}), 7.36(1 \mathrm{H}, \mathrm{t}), 7.62(1 \mathrm{H}, \mathrm{d}, J=7.8 \mathrm{~Hz}), 7.98(1 \mathrm{H}, \mathrm{d}, J=6.2 \mathrm{~Hz}), 8.56(1 \mathrm{H}, \mathrm{t})$. 


\section{General procedure of intramolecular amidoalkylation for the preparation of 1 and 5}

A compound 3 (2-10 mmol) was dried under vacuum with $\mathrm{P}_{2} \mathrm{O}_{5}$ for a day, dissolved in absolute formic acid ( $3 \mathrm{~mL}$ of the acid per $100 \mathrm{mg}$ of 3 if no other ratio is specified), and the mixture was allowed to stand the required time at rt (TLC control). The acid was evaporated under reduced pressure, and the reaction mixture was dissolved in chloroform or dichloromethane (6-8 mmol of the mixture per $100 \mathrm{~mL}$ of solvent). It was washed with a saturated solution of sodium carbonate $(20 \mathrm{~mL})$, with a saturated solution of sodium chloride $(20 \mathrm{~mL})$ and then with water $(20 \mathrm{~mL})$. The solution of substance 4/5 was filtered through cotton wool and the solvent was evaporated. After these general procedures a specific purification was followed.

\section{4-Benzyl-3a,6a-dimethyl-4-isopropenylhexahydro-1-oxa-3-azapentalen-2-one (4a).}

This product was obtained from $1.82 \mathrm{~g}(6 \mathrm{mmol})$ of oxazolidinone 3a during $168 \mathrm{~h}$. Hexane (4 $\mathrm{mL}$ ) was added to the reaction mixture with trituration, the crystals which formed were washed with hexane to give a white powder $(1.10 \mathrm{~g}, 65 \%) ; \mathrm{mp}=90-92{ }^{\circ} \mathrm{C}$; MS M+ 285, 204, 203, 92, 91; IR 1640, $1735 \mathrm{~cm}^{-1}$; Anal. Calcd for $\mathrm{C}_{18} \mathrm{H}_{23} \mathrm{NO}_{2}$. Found: $\mathrm{C} 75.98, \mathrm{H} \mathrm{8.10,} \mathrm{N} \mathrm{4.92;} \mathrm{calcd:} \mathrm{C}$ 75.75, $\mathrm{H}$ 8.12, N 4.91; ${ }^{1} \mathrm{H}$ NMR $\left(\mathrm{CDCl}_{3}\right) \delta 1.10(3 \mathrm{H}, \mathrm{s}), 1.33(3 \mathrm{H}, \mathrm{s}), 1.48-1.73(2 \mathrm{H}, \mathrm{m}), 1.90$ $(3 \mathrm{H}, \mathrm{s}), 1.92-2.08(2 \mathrm{H}, \mathrm{m}), 2.17(1 \mathrm{H}, \mathrm{d}$ of d), $2.32(1 \mathrm{H}, \mathrm{d}$ of d), $4.02(1 \mathrm{H}, \mathrm{d}, J=17.4 \mathrm{~Hz}), 4.48$ $(1 \mathrm{H}, \mathrm{d}, J=1.0 \mathrm{~Hz}), 4.82(1 \mathrm{H}, \mathrm{d}, J=17.4 \mathrm{~Hz}), 5.08(1 \mathrm{H}, \mathrm{d}, J=1.0 \mathrm{~Hz}), 7.18-7.24(5 \mathrm{H}, \mathrm{m})$.

\section{3a,6a-Dimethyl-3-(2-cyanethyl)-4-isopropenylhexahydro-1-oxa-3-azapentalen-2-one} This compound was obtained from $2.13 \mathrm{~g}(8 \mathrm{mmol})$ of oxazolidinone 3c during $72 \mathrm{~h}$. Hexane (4 $\mathrm{mL}$ ) was added to the reaction mixture and with trituration and cooling the crystals which formed were washed with hexane to afford white crystals $(1.90 \mathrm{~g}, 96 \%)$; $\mathrm{mp}=91-93{ }^{\circ} \mathrm{C}$; MS M+ 248, 167, 166, 126, 123; IR 1640, 1725, $2263 \mathrm{~cm}^{-1 ;}$ Anal. Calcd for $\mathrm{C}_{14} \mathrm{H}_{20} \mathrm{~N}_{2} \mathrm{O}_{2}$. Found: C 67.51, H 8.14, N 11.31; calcd: C 67.71, H 8.12, N 11.28; ${ }^{1} \mathrm{H}$ NMR (DMSO-d $\left.{ }_{6}\right) \delta 1.35(3 \mathrm{H}, \mathrm{s}), 1.42(3 \mathrm{H}$, s), 1.52-1.86 (3H, m), $1.80(3 \mathrm{H}, \mathrm{s}), 1.87-2.08(1 \mathrm{H}, \mathrm{m}), 2.35(1 \mathrm{H}, \mathrm{d}$ of d), 2.54-2.88 $(2 \mathrm{H}, \mathrm{m})$, 3.08-3.22 (1H, m), $4.90(1 \mathrm{H}, \mathrm{d}, J=1.0 \mathrm{~Hz}), 5.00(1 \mathrm{H}, \mathrm{d}, J=1.0 \mathrm{~Hz})$.

\section{3-Allyl-3a,6a-dimethyl-4-isopropenylhexahydro-1-oxa-3-azapentalen-2-one (4c).}

This compound was obtained from $2.02 \mathrm{~g}$ ( $8 \mathrm{mmol})$ of oxazolidinone 3e during $95 \mathrm{~h}$. Hexane $(3$ $\mathrm{mL}$ ) was added to the oil with trituration and cooling the crystals which precipitated were washed with hexane to yield with a white product $(0.57 \mathrm{~g}, 30 \%)$. The substance did not show a sharp mp and melted in the interval 51-64 ${ }^{\circ} \mathrm{C}$; MS M+ 235, 153, 152, 122, 112; IR 1640, 1730 $\mathrm{cm}^{-1} ;{ }^{1} \mathrm{H}$ NMR $\left(\mathrm{CDCl}_{3}\right) \delta 1.33(3 \mathrm{H}, \mathrm{s}), 1.37(3 \mathrm{H}, \mathrm{s}), 1.44-1.70(2 \mathrm{H}, \mathrm{m}), 1.80(3 \mathrm{H}, \mathrm{s}), 1.84-2.00$ $(1 \mathrm{H}, \mathrm{m}), 2.13(1 \mathrm{H}, \mathrm{d}$ of d), $2.27(1 \mathrm{H}, \mathrm{d}$ of d), $3.50(1 \mathrm{H}, \mathrm{d}$ of d, $J=7.4, J=14.7 \mathrm{~Hz}), 4.02(1 \mathrm{H}$, 
m), $4.92(1 \mathrm{H}, \mathrm{d}, J=1.0 \mathrm{~Hz}), 5.00(1 \mathrm{H}, \mathrm{d}, J=1.0 \mathrm{~Hz}), 5.08(2 \mathrm{H}, \mathrm{d}$ of d, $J=1.0, J=5.9 \mathrm{~Hz}), 5.15$ $(1 \mathrm{H}, \mathrm{d}$ of $\mathrm{d}, J=1.0, J=14 \mathrm{~Hz}), 5.70-5.88(1 \mathrm{H}, \mathrm{m})$.

\section{3a,6a-Dimethyl-4-isopropenyl-3-(2-formyloxyethyl)hexahydro-1-oxa-3-azapentalen-2-one} (4d).

A solution of dioxolanone $1 \mathrm{a}(1.74 \mathrm{~g}, 8.87 \mathrm{mmol})$ and ethanolamine $(2 \mathbf{e})(0.54 \mathrm{~g}, 8.87 \mathrm{mmol})$ in $15 \mathrm{~mL}$ of dichloromethane was allowed to stand $48 \mathrm{~h}$ at $\mathrm{rt}$ (TLC control) and the solvent was evaporated. The dried residue (3f) was dissolved in formic acid and allowed to stand $48 \mathrm{~h}$ at $\mathrm{rt}$, then the mixture was processed as described in the general technique. The product obtained was purified as in the case of $\mathbf{4 b}$ to afford $1.63 \mathrm{~g},(69 \%)$ of white crystals; mp $=69-71{ }^{\circ} \mathrm{C}$; MS M+ 267, 186, 185, 140, 96; IR 1640, $1720 \mathrm{~cm}^{-1}$; Anal. Calcd for $\mathrm{C}_{14} \mathrm{H}_{21} \mathrm{~N}_{2} \mathrm{O}_{4}$. Found: C 63.08, $\mathrm{H}$ 7.94, N 5.22; calcd: C 62.90, H 7.92, N 5.24; ${ }^{1} \mathrm{H}$ NMR $\left(\mathrm{CDCl}_{3}\right) \delta 1.36(3 \mathrm{H}, \mathrm{s}), 1.37(3 \mathrm{H}, \mathrm{s})$, 1.45-1.60 (2H, m), $1.88(3 \mathrm{H}, \mathrm{s}), 1.90(1 \mathrm{H}, \mathrm{d}$ of d), $2.13(1 \mathrm{H}, \mathrm{d}$ of d), 2.39 (1H, d of d), 3.11-3.27 $(1 \mathrm{H}, \mathrm{m}), 3.52-3.66(1 \mathrm{H}, \mathrm{m}), 4.20-4.35(2 \mathrm{H}, \mathrm{m}), 4.91(1 \mathrm{H}, \mathrm{d}, J=1.0 \mathrm{~Hz}), 5.01(1 \mathrm{H}, \mathrm{d}, J=1.0$ $\mathrm{Hz}), 8.05(1 \mathrm{H}, \mathrm{s})$.

3a,6a-Dimethyl-3-dimethylamino-4-isopropenylhexahydro-1-oxa-3-azapentalen-2-one (4e). This compound was obtained from $2.56 \mathrm{~g}(10 \mathrm{mmol})$ of oxazolidinone $3 \mathbf{e}$ in $34 \mathrm{~mL}$ of formic acid during $120 \mathrm{~h}$ at $\mathrm{rt}$. The colorless viscous mass which formed was dissolved in $10 \mathrm{~mL}$ of boiling hexane and allowed to crystallize $24 \mathrm{~h}$ at $\mathrm{rt}$. The precipitated crystals were collected by filtration, washed with hexane $(3 \times 2 \mathrm{~mL})$ to afford $1.00 \mathrm{~g}$ of 4e. (Washings of several experiments were combined, hexane was evaporated, the mixture was purified by chromatography to give $1.47 \mathrm{~g}$ of the crude product after chromatographic isolation and crystallization from $2 \mathrm{~mL}$ of hexane and washing with cool hexane $(2 \times 1 \mathrm{~mL})$ gave $0.62 \mathrm{~g} \mathrm{(43 \% )}$ of $\mathbf{4 e}$ as a white powder; total yield calcd is $84 \%$.) $\mathrm{mp}=111-113{ }^{\circ} \mathrm{C}$; $\mathrm{MS} \mathrm{M}+238,196,145,137$, 125; IR 1640, $1735 \mathrm{~cm}^{-1}$; Anal. Calcd for $\mathrm{C}_{13} \mathrm{H}_{22} \mathrm{~N}_{2} \mathrm{O}_{2}$. Found: $\mathrm{C}$ 65.31, H 9.32, N 11.78; calcd: C 65.51, H 9.30, N 11.75. 1H NMR (CDCl3) 1.34 (3H, s), 1.49 (3H, s), 1.50-1.94 (5H, m), 2.00 $(3 \mathrm{H}, \mathrm{s}), 2.73(3 \mathrm{H}, \mathrm{s}), 2.80(3 \mathrm{H}, \mathrm{s}), 4.89(1 \mathrm{H}, \mathrm{d}, J=1.0 \mathrm{~Hz}), 4.93(1 \mathrm{H}, \mathrm{d}, J=1.0 \mathrm{~Hz})$.

3a,6a-Dimethyl-4-cis,trans-isopropenyl-4-[(pyridyl-2)methyl]hexahydro-1-oxa-3-azapentalen-2one (4f'/4f"); 3a,6a-dimethyl-4-trans-(methyl-1-formyloxy)-4-[(pyridyl-2)methyl]hexahydro-1oxa-3-azapentalen-2-one(5') and its cis isomer 5": These products were obtained from $2.13 \mathrm{~g}$ (7.29 mmol) of oxazolidinone $3 \mathrm{~b}$ during $48 \mathrm{~h}$ as $2.40 \mathrm{~g}$ of a dark viscous oil. Then $10 \mathrm{~mL}$ of ether-hexane 1:1 was added to the oil with trituration and cooling. The solvent solvent was removed by decantation and two tof he operations were repeated three times more to yield $1.17 \mathrm{~g}$ of crystals. After crystallization from ether-hexane they yielded $5(0.86 \mathrm{~g}, 38 \%)$ as light brown 
crystals. The combined washings were evaporated, a residue was separated by chromatography, 4f'/4f" (0.62 g, 31\%, an oil) and 5" (0.58 g, 26\%, an oil) were obtained. Summary yield of 4f/4f", $5^{\prime}$ and 5" 95\%; 4f/4f" ${ }^{1} \mathrm{H}$ NMR (DMSO-d 6 ) $\delta 1.09,1.21(3 \mathrm{H}, 2 \mathrm{~s}), 1.49(3 \mathrm{H}, \mathrm{s}), 1.05-2.48(5 \mathrm{H}$, m), 1.61, $1.89(3 \mathrm{H}, 2 \mathrm{~s}),\{[4.13(\mathrm{~d}, J=16.7 \mathrm{~Hz}), 4.62(\mathrm{~d}, J=16.7 \mathrm{~Hz})],[4.49(\mathrm{~d}, J=16.7 \mathrm{~Hz})$, $4.85(\mathrm{~d}, J=16.7 \mathrm{~Hz})], 2 \mathrm{H}\}, 4.95(1 \mathrm{H}, \mathrm{d}, J=1.0 \mathrm{~Hz}), 5.06(1 \mathrm{H}, \mathrm{d}, J=1 \mathrm{~Hz}), 7.16-7.32(2 \mathrm{H}, \mathrm{m})$, 7.66-7.80 (1H, m), 8.41-8.56 (1H, m).; 5: $\left(\mathrm{mp}=144-146{ }^{\circ} \mathrm{C} ; \mathrm{MS} \mathrm{M}+332,287,243,227,204\right.$; IR $1745 \mathrm{~cm}^{-1}$; Anal. Calcd for $\mathrm{C}_{18} \mathrm{H}_{24} \mathrm{~N}_{2} \mathrm{O}_{4}$. Found: $\mathrm{C}$ 65.23, H 7.26, N 8.41; calcd: C 65.04, $\mathrm{H}$ 7.28, N 8.43; ${ }^{1} \mathrm{H}$ NMR (DMSO-d 6 ) $\delta 1.24(3 \mathrm{H}, \mathrm{s}), 1.40(3 \mathrm{H}, \mathrm{s}), 1.52(3 \mathrm{H}, \mathrm{s}), 1.60-1.80(3 \mathrm{H}, \mathrm{m})$, $1.63(3 \mathrm{H}, \mathrm{s}), 1.90-2.10(1 \mathrm{H}, \mathrm{m}), 2.16-2.30(1 \mathrm{H}, \mathrm{m}), 4.40(1 \mathrm{H}, \mathrm{d}, J=16.1 \mathrm{~Hz}), 4.56(1 \mathrm{H}, \mathrm{d}, J=$ $16.1 \mathrm{~Hz}), 7.21(1 \mathrm{H}, \mathrm{d}$ of d, $J=5.6, J=8.1 \mathrm{~Hz}), 7.30(1 \mathrm{H}, \mathrm{d}, J=8.1 \mathrm{~Hz}), 7.72(1 \mathrm{H}, \mathrm{t}), 8.36(1 \mathrm{H}$,

s), $8.48(1 \mathrm{H}, \mathrm{d}, J=6.4 \mathrm{~Hz})$; 5"; (MS of this compound coincides with MS of 5); IR $1730 \mathrm{~cm}^{-1}$; ${ }^{1} \mathrm{H}$ NMR (DMSO-d $) \delta 1.26(3 \mathrm{H}, \mathrm{s}), 1.36(3 \mathrm{H}, \mathrm{s}), 1.50-1.70(1 \mathrm{H}, \mathrm{m}), 1.51(3 \mathrm{H}, \mathrm{s}), 1.59(3 \mathrm{H}, \mathrm{s})$, 1.80-2.20 (3H, m), $2.52(1 \mathrm{H}, \mathrm{d}$ of d), $8.16(1 \mathrm{H}, \mathrm{s}), 4.48(1 \mathrm{H}, \mathrm{d}, J=21.9 \mathrm{~Hz}), 4.60(1 \mathrm{H}, \mathrm{d}, J=$ $21.9 \mathrm{~Hz}), 7.24(1 \mathrm{H}, \mathrm{d}$ of d, $J=6.6, J=9.8 \mathrm{~Hz}), 7.36(1 \mathrm{H}, \mathrm{d}, J=9.8 \mathrm{~Hz}), 7.71(1 \mathrm{H}, \mathrm{t}), 8.16(1 \mathrm{H}$, s), $8.50(1 \mathrm{H}, \mathrm{d}, J=5.5 \mathrm{~Hz}))$.

\section{References}

1. Serebryakov, E.P.; Nignatov, A.G.; Shcherbakov, M.A.; Struchkova, M.I. Isv. Akad. Nauk. Ser. Khim. 1998, 1, 84 (Russ. Chem. Bull. 1998, 1, 74). (b) Belokon, Yu.N.; Kochetkov, K.A.; Churkina, T.D.; Chesnokov, A.A.; Smirnov, V.V; Ikonnikov, N.S; Orlova, S.A. Isv. Akad. Nauk. Ser. Khim. 1998, 1, 76 (Russ. Chem. Bull. 1998, 1, 82). (c) Corey, E.J; Link, J.O. Tetrahedron Lett. 1990, 31, 601

2. Schneider, K.; Best, W. Ger. Pat. 3,433,403 A1 1986.

3. Chernysheva, N.B; Bogolyubov, N.A.A; Semenov, V.V. Khim. Geterotsikl. Soedin. 1999, 2 241 (Chemistry of Heterocyclic Compounds 1999 35, 216)

4. Collado,M.I.; Sotomayor, N.; Villa, M.J.; Lete, E. Tetrahedron Lett. 1996, 37, 6193

5. Collado, M.I.; Manteca, I.; Sotomayor, N.; Villa, M.J.; Lete E. J. Org. Chem. 1997, 62, 2080

6. Ishuzuka, T.;Ishubuchi, S.; Kunieda, T. Tetrahedron 1993, 49, 1841

7. Specamp, W.N.; Hiemstra, H. Tetrahedron 1985, 41, 4367

8. Hamesma, J.A.M; Nossin, P.M.M.; Speckamp,W.N. Tetrahedron 1985, 41, 1999

9. Ed. Burgi H.B.; Dunitz, J.D. Structure correlation, VCH Publishers, NY 1994 v1 
10. Sharp, J.T.; Gosney, I.; Rowley, A.G. Practical Organic Chemistr;, Champman and Hall: NY 1988. 